\section{Inclusive masculinity and Czechia youth}

\section{Viktor Chvatík, Jack Hardwicke $i$ and Eric Anderson}

Department of Sport, Exercise and Health, University of Winchester, UK

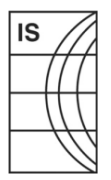

International Sociology

$1-19$

(C) The Author(s) 2021

(c) (i)

Article reuse guidelines: sagepub.com/journals-permissions DOI: 10.1 I77/0268580921। 046599 journals.sagepub.com/home/iss

(S)SAGE

\begin{abstract}
In this, the first investigation of inclusive masculinities among 18- to 19-year-old Czech students, the authors interviewed 19 participants from a rural part of the country. The purpose of this research was to identify attitudes of young, rural, Czech men toward homosexuality and examine for perceived generational difference compared to men who emerged under communism. Results showed evidence of inclusive masculinities for these rural youth based in three principal categories: (I) positive attitudes toward homosexuality; (2) openness to a bromance with a gay male (dependent on gender typicality); and (3) perceived generational differences in gay acceptance compared to their parents' generation. Overall, results therefore show that young men in this rural part of Czechia are enacting more inclusive forms of masculinity than possible under communist rule.
\end{abstract}

\title{
Keywords
}

Gender, inclusive masculinity, rural, youth

\section{Introduction}

Borkowska (2018) has recently described masculinity studies occurring in three theoretical stages, of which the latest she describes as 'Andersonian' (p. 3). This, she argues, is because recent masculinity research has shown a shift from hyper or orthodox forms of masculinity to those that are softer in their measurable presentations. Anderson's (2009) theoretical model of explicating this level of masculinity comes through his notion of homohysteria which takes multiple variables into account in order to make predictions about what masculine behaviours and attitudes will be acceptable to adolescent youth.

Part of this emerging body of inclusive masculinity research is also focused on the relatively new term 'bromance', which describes a close relationship between two, usually

\footnotetext{
Corresponding author:

Jack Hardwicke, University of Northampton, Department of Life Sciences, NNI 5PH, UK.

Email: jackhardwickephd@googlemail.com
} 
heterosexual, men (DeAngelis, 2014), focusing on emotional and physical attributes (Robinson et al., 2018, 2019). The bromance serves as valuable evidence as to how heterosexuality has expanded in recent years (Anderson, 2018).

While there is a growing body of research documenting a more feminine set of behaviours for men (see Anderson and McCormack, 2018 for an overview of these trends), the theory has been bounded by a focus on Western and English-speaking countries, not examining dynamics of masculinities in an Eastern or Central European context. Furthermore, the research has focused on men in urban and semi-urban settings, with little research on rural contexts. This study thus contributes to research in this area by examining the dynamics of men and masculinities in a formerly Eastern Bloc country, that of Czechia (now considered Central Europe), examining a small town, far from metropolitan areas.

\section{Theorizing masculinities}

Masculinity, as a study of boy's and men's gendered behaviours, started to be properly examined in the last few decades of the 20th century. Despite some early research being engaged with how to help men, the sub-discipline has come to focus on the social problems caused by masculinity. This included both examining the privilege gained by men through their gender (Lorber, 1994) and the social costs to girls and women (Borkowska, 2018).

The esteemed form of masculinity of the late 20th century was described as being tough, stoic and rooted in a rejection of feminine behaviours. The idea of being masculine consisted of no sissy stuff; be a big wheel; be sturdy as an oak; and boys were to give (other boys) 'em hell (Brannon and David, 1976). This led to social expectations that boys would not show fear or weakness, and to hide all trace of inadequacy, or anxiety. These masculine attributes are labelled by Anderson (2005) as 'orthodox masculinity' and are described as maintaining negative social values in many, but not all, social contexts. Anderson's notions of orthodox masculinity also include men being either a leader, or an independent man (like a cowboy). Men who followed this orthodox code were thought to, in some ways, gain privilege and prestige, both among men and collectively over women (Anderson, 2009). But they were also thought to pay a price for this 'privilege'.

Social norms related to traditional forms of masculinities therefore encouraged men to put their health at risk (Courtenay, 2000) and also cause damage by avoiding and stigmatizing behaviours that have been associated with positive mental and emotional health (Way, 2011).

Plummer (1999) contended that emotional expressionism, intellectual endeavours, physical tactility and exhibiting caring behaviours were all stigmatized due to their association with femininity. The rejection of homosocial intimacy was evident in many contexts throughout the 1980s and 1990s, in Western cultures, and likely influenced internalized desires for how men wished to perceive themselves (Floyd, 2000; McCreary, 1994). The hyper-masculine standards of the time caused very different homosocial behaviours than we are seeing among young men in contemporary research (Adams, 2011; Anderson and McGuire, 2010; Morris and Anderson, 2015). 
Hegemonic Masculinity Theory became the dominant approach to understand the social processes and, overall, the masculinity of the late 20th century (Connell, 1995; Connell and Messerschmidt, 2005). One important component was how Connell recognized that masculinities were multiple, fragmented and contested. Perhaps the most successful part of her theorizing was understanding the stratification of men. Connell (1987) designated three categories of masculinities that, by definition, were thought to emerge 'under' the hegemonic form: complicit, subordinated and marginalized. This conceptualization held that boys and men who most closely embody hegemonic masculinity are accorded the most social capital, relative to other boys and men.

Some of the characteristics of hegemonic masculinity concern variables which are earned, like attitudinal depositions (including the disposition of homophobia), while other variables concern static traits (i.e. whiteness, heterosexuality and youth); these then form the middle category called subordinated masculinity. Connell first argued, however, that regardless of body mass, age or even sporting accomplishments, gay men are at the bottom of this hierarchy, in a category of marginalized masculinity. Connell later revised this, however, to suggest that gay men might be accepted as masculine, and thus part of the patriarchy (Connell and Messerschmidt, 2005).

Connell also argued that heterosexual men who behaved in ways that conflict with the dominant form of masculinity are also marginalized. This thus not only raised an issue of oppression, subordination and exclusion of gay men (Connell, 1995; Kimmel, 1995; Plummer, 1999), but it meant that straight men who did not measure up to hegemonic masculinity also suffered. Essentially, she argued that men were attempting to distance themselves from subordinate status by promoting their attitudes about homosexuality and masculinity in accord with orthodox masculinity. This then creates a fraternal system which continues in reproducing hegemonic masculinity through an institutionalized, gender-segregated, racially exclusive, sexist, and highly homophobic masculine peer culture (Martin and Hummer, 1989; Ross, 1999; Sanday, 1990).

Hegemonic masculinity theory undoubtedly helped scholars understand, and explain, the development of masculinity in the late 1980s and 1990s. However, the increasing inclusion of gay men in young men's peer groups is well beyond what hegemonic masculinity scholars were documenting in the decades earlier (Anderson, 2002, 2009; McCormack, 2012). Hegemonic masculinity theory failed to explain these new findings and therefore also failed to properly conceptualise these new forms of masculinity. To fill the theoretical gap and offer a more contextualized understanding of the relationship between homophobia and masculinity, Anderson (2009) devised Inclusive Masculinity Theory (IMT), which has recently been described as the third and most recent wave of masculinity scholarship (Borkowska, 2018).

According to Anderson and McCormack (2018: 549): '[IMT] was developed to explain sport and fraternity settings where the social dynamics were not predicated on homophobia, stoicism or a rejection of the feminine'. The theory emerged based on research findings which indicate more inclusive behaviours of heterosexual men, and the changing dynamics of male peer group cultures in the US and UK. Many young straight males include gay peers in friendship networks, are more emotionally intimate with friends, are physically tactile with other men, recognize bisexuality as a legitimate sexual orientation, embrace activities and artefacts once coded feminine and eschew violence 
and bullying (see McCormack and Anderson, 2014b for a summary of these findings). Thus, research suggests that masculinity in British and American, as well as other AngloAmerican societies (Clements and Field, 2014; Twenge et al., 2016), is slowly shifting from hegemonic to more inclusive (Anderson, 2009, 2015; McCormack, 2012; Roberts, 2018).

However, masculinity is shifting in other countries too, and not just in Western ones. Based on recent research findings the shift is recognizable in countries such as Spain, Bangladesh, India, and China. In each of these countries evidence of the shift from hegemonic to more inclusive masculinity comes in different contexts. In Spain, Villanova et al. (2018) interviewed the first openly gay athlete in a team sport. The athlete has not experienced any negative reactions during the process of coming out. Research from Bangladesh (Hasan et al., 2018) shows how the perception of 'real' men differs in respect to work, religion and sexuality by social generations. Similar generational difference regarding masculinity was also recorded in India by Philip (2018). More evidence of the shift in different contexts comes from China, where the inclusivity is recognizable based on interpretation of Chinese film posters which show a shift from orthodox to inclusive masculinities ( $\mathrm{Hu}, 2018)$.

As the research suggests, the nature of British as well as other nations' masculinity, is changing. When taken together with the already large body of scholarship showing dramatic shifts (cf. Anderson, 2015), these articles show that the shifts being documented since the latter part of the first decade of the twenty-first century are both profound and enduring. The shift in masculinity is not identical in every region, because cultures develop differently and therefore men in one culture can be more inclusive than men in other cultures. However, the shift in masculinity is now being recognized in many cultures and there is now a considerable body of qualitative and quantitative research highlighting that masculinity is shifting in response to both the awareness of and decreasing antipathy towards homosexuality (McCormack and Anderson, 2014a, 2014b), as well as other religious, cultural, economic and political factors (Roberts, 2014). This research adds to the corpus of literature on Inclusive Masculinity Theory (IMT) by examining a Central European country, and a rural location simultaneously.

\section{Homohysteria}

Anderson (2009, 2011), Anderson and McCormack (2018) and McCormack and Anderson (2014a) suggest that homophobia serves as the primary policing mechanism of polarized gendered identities (male and female) due to heterosexual men's inability to definitively prove their heterosexuality to others. This means that men must accept and follow the behaviour and attitudes that are coded in a society as masculine to avoid homosexual suspicion. Anderson (2009) and McCormack (2011) showed that the once highly-restricted set of masculine behaviours socially expected of heterosexual men has, however, radically expanded in recent years, and notably around the turn of the $21 \mathrm{st}$ century.

IMT is based on research findings from peer group cultures in the US and the UK. It might seem that the changes in masculinity highlighted above are caused by a decline in homophobic attitudes in the US, UK and other Western countries. However, similar 
homosocial tactility as well as open expression of masculinities exist in other cultures where homophobia is present. To explain this issue, and historically and geographically situate IMT, Anderson (2009) introduces the concept of homohysteria.

Homohysteria is understood as the fear of being socially perceived as gay. A homohysteric culture necessitates three factors: (1) widespread awareness that homosexuality exists as a static sexual orientation within a given culture; (2) cultural disapproval towards homosexuality (i.e. homonegativity); and (3) disapproval of men's femininity due to association with homosexuality. For homohysteria to persist, all three conditions must be maintaned. Thus, when these conditions are met, homophobia might be used as a tool to police gender, this is because people living under these conditions fear the stigma of being socially perceived as gay.

Homohysteria is a crucial factor for understanding IMT because it is a concept that explains social change. Essentially, the term homohysteria describes the social conditions in which homophobia influences men's behaviours (Anderson, 2011). The theory suggests that in homohysteric cultures men are forced to behave in certain ways and follow given patterns in order to avoid the accusation of being gay. Similarly, as in Connell's (1995) hegemonic masculinity theory, in homohysteric cultures, there is one dominant form of masculinity which is culturally exalted.

This means, that at the end of the 20th century, anyone who feared being perceived as gay aligned their behaviours in anything socially perceived as opposite in order to cast off homosexual suspicion (Burstyn, 1999). Thus, an example how homohysteria distances heterosexual men from each other, emotionally, was the inability for men to even admit liking one another.

The level of homohysteria differs in every culture and it also changes over time. Anderson (2009) argues that - as the 20th century progressed - homohysteria grew to such an extent that even a hug between men became symbolic of homosexuality (Derlega et al., 2001). Research on men and their masculinities in the 1970s and 1980s continued to show men in a state of homohysteria until around the turn of the 21 st century.

IMT offers the link between men's gendered behaviours and the social trend of decreasing homophobia; in this it explains variance between cultures and generations. According to IMT, when homohysteria decreases the change in masculinities will follow. Anderson (2009) argues that the stratifications of men become less hierarchical, and that more diverse forms of masculinity become more evenly esteemed. In this context, it would mean that femininity in men becomes less stigmatized, and the specific and narrow set of activities, that are valued by men, expand. Non-conforming masculinities would also be less regulated.

These changes would then cause heterosexuality to expand. The fact that this might be already happening can be supported with the fact that young people increasingly do not define themselves as exclusively straight or exclusively gay (Savin-Williams, 2009; Vrangalova and Savin-Williams, 2012). This could indicate that Kinsey et al.'s (1948) recognition of sexuality as a continuum is now being adopted by young people.

Evidencing just some of the Inclusive Masculinity research findings, research shows, for example, that 16- to 18-year-old British high school students enjoy homosocial hugging (McCormack and Anderson, 2010). Similar homosocial behaviour is also observed, for example, among scholastic wrestlers without such forms of identity management 
(Baker and Hotek, 2011). Adams (2011) documented that US soccer players regularly engage in gentle forms of same-sex touch, including hugging as a greeting and as a way of providing comfort and support (see also Adams and Kavanagh, 2018; Anderson et al., 2012b; Kaplan, 2006; Magrath and Scoats, 2017; Magrath et al., 2015; Roberts, 2013, 2018).

Magrath (2016) found similar behaviours in UK academy football. His research findings show that professional football players would engage in same-sex touch as a form of emotional support for one another. Similarly, Anderson et al.'s (2012a) findings show that, from 145 interviews of heterosexual male students at a UK university, 89\% have at some point kissed another male on the lips, which they reported as being non-sexual. This study was repeated in Australia (Drummond et al., 2015) and found that, among the 90 heterosexual men interviewed, 29\% report having engaged in at least one same-sex kiss. This number is smaller in a study of 11 US universities, where $10 \%$ kissed on the lips and $40 \%$ on the cheeks (Anderson et al., 2019).

\section{Masculinity and homosexuality in Czechia}

Czechia used to be one country with Slovakia called Czechoslovakia. It was governed by totalitarian communism between 1948 and 1989. This meant that inhabitants of Czechoslovakia were not allowed to travel behind the borders. The situation was so dire that communist soldiers were rewarded for capturing or killing refugees (Janda, 2010; Kuznik and Beranek, 2005). Thus, the political regime sequestered people and denied freedom of expression. Exemplifying this, inhabitants could not express individuality in consumerism. All had to follow the political regime and accommodate its social and material conditions. Pyšňáková and Miles (2010: 27) examined how the post-revolutionary generation is affected by consumerism, finding that: 'Consumption provides an important means by which young people face the challenges inherent in the emergence of an increasingly individualised culture' and urge researchers to examine consumerism in Czechia more.

Communism brought not just the lack of individualism, its political propaganda also set up a different mindset and perception of masculinity. During communism, the heroes of the nation became regular men from the working-classes. Moreover, the Soviet Union created a prototype of a 'New Soviet Man' who carried its specific characteristic. Though Czechoslovakia or the Czech Republic have never been part of the Soviet Union, under the rule of communism it became a satellite of the Soviet Union. The archetypes of the 'New Soviet man' archetype were thus heavily promoted.

The archetype of a 'New Soviet Man' was one who was selfless, learned, healthy and muscular and enthusiastic in spreading and adhering to socialism (Overy, 2004). Examples of how the prototype of a Soviet man was propagated in posters and other printed media in Czechoslovakia can be viewed on Google images or any poster gallery focused on communism in Czechoslovakia. Most often the pictures represent men and masculinity in three main ways:

1. a picture of a strong man with a tool in his hand (hammer, etc.) or in working clothes with happy wife and children in the background, 
2. an athlete (who is ready to work and also ready for the country's defence),

3. or a soldier (being honoured or registering for military service).

These pictures, posters and other media used for propaganda were also filled with communistic slogans, such as: Vojenská služba je nejvyšší ctí našeho občana (The military service is the highest honour of our citizen), Se Sovětským svazem na věčné časy! (With Soviet Union Forever!), Dohnat a předehnat! (To catch up and get ahead [of rotting capitalist countries]!), Ani zrno nazmar! (No grain to waste!) (Posters.nce, n.d.). More about masculinities and the struggle of working-class men under communism can be found in the work of Walker (e.g. 2016, 2017).

Because antipathy toward homosexuality is the central tenant of Anderson's theorizing of inclusive masculinities, it is also important to note that homosexuality in Czechoslovakia was illegal until 1961, and people who were suspected of being homosexual were tracked down and prosecuted. State organizations often used homosexuality as a tool for blackmail if they needed to obtain information (Erban, 2015). However, it must be said that the state-socialist regime never enacted a hateful campaign against nonheterosexual people. As Sokolová (2014: 82) writes:

... there certainly was public contempt for homosexuality in state-socialist Czechoslovakia but such popular attitudes pre-dated the state-socialist regime's accession to power and cannot be interpreted as a 'communist invention.' The one-party state did not support diversity and found all identities that challenged state-socialist ideology as suspect. In this case, the repressive apparatus did not care or target homosexuals or transsexuals in any different ways than, for example, hippies, rockers, or believers.

This social antipathy toward homosexuality meant that the Czech Republic's former political regime encultured people to become more sexually conservative and xenophobic (Burjanek and Retter, 2001). This influence then began to wane with the collapse of communism during the 1989 Velvet Revolution. Thus, the men of this study have never lived under communism. Instead, they live in an advanced capitalistic democracy that is aligned with the ethos of Europe more broadly. There is limited previous research on masculinities within the contemporary context of Czechia, with this being the first study examining inclusive masculinity in this location. However, Šmídová's (2009) findings present the changing nature of masculinities in the Czech context as they relate to the political climate, offering the grounding for the present study.

\section{Methods}

There were three aims to this study. The first is to examine the attitudes of the rural Czech youth interviewed toward male homosexuality. The second was to discover if there are any perceptions of differences in masculinity between the participants' generation (millennials) and older generations. Third, this study aimed to see if Anderson's (2009) Inclusive Masculinity Theory is applicable in Central Europe, specifically within Czechia. In order to accomplish these aims we modelled this research on the corpus of work related to inclusive masculinity scholarship in the West. 


\section{Research design}

In line with previous research on inclusive masculinities, the participants of this research were selected for their representation as millennials - born around the year 2000 (for this study, no younger than 18 and no older than 22). The research uses semi-structured interviews to hold steady variables of analysis and in order to compare them to research findings of the same topic in the UK (e.g. Anderson and Fidler, 2018). This particular qualitative study is not triangulated with observations or quantitative measures; there are, however, plans for that research. The results of this work thus emerge from thematic coding of interview data (Braun and Clarke, 2006), alongside descriptive statistics of tactile behaviours between men.

As a study of this type has never been done in Czechia, the questions had to be carefully considered. This is particularly true because the participants are native Czech speakers. To facilitate this, the lead author (whose primary language is Czech) consulted with native English speakers in formulating the questions. This is thus research on Czech youth, conducted and translated into English by a Czech native.

\section{Participants}

The demographic of participants for this research were strategically selected in order to mirror much of the work done on youth populations in English-speaking studies of inclusive masculinities. Criteria were that these young men must first identify themselves as heterosexual, and they must have been raised in Czechia since being a young child.

Following the procedures outlined below, 19 white millennial males who are permanent citizens of Czechia and speak native Czech were interviewed. All were aged between 18 and 20 at the time of data collection in 2017. All participants were students with no employment, including part-time work, and reported being financially supported by parents. Our participants all identified as being single and none reported having children.

All participants were recruited from the same grammar school in this rural part of the country. The reason for selecting students from one school are two-fold. Firstly, grammar school students in Czechia are often considered 'the intelligence of the nation', as it is expected that they will go to a university. It was the connections that this grammar school has with universities that led us to believe that they would support this study and grant institutional access - which they did.

Secondly, as this article is only focused on potentially intellectual students, it brings up the possibility for future research. The results can someday be compared to the results from any average Czech high school. This is research that we have planned. This future research could thus reveal any potential differences in attitudes towards gay culture or homosocial tactility between potential workers and potential university students.

The socio-economic background of these participants is consistent with the large body of inclusive masculinities scholarship on middle-class youth (Anderson and Magrath, 2019). An important distinction, however, is that these participants lived in a rural area of Eastern Europe. Previous research into inclusive masculinities has largely focused on men in urban, and semi-urban, settings in Western and English-speaking countries. Thus, this study extends this enquiry through examining the dynamics of men and masculinities in a small rural town situated in Czechia. 


\section{Procedures}

After being granted institutional access, we were able to recruit 19 students (without remuneration) who fit the demographic profile for interview. This was accomplished by giving a short talk to students in one class about the research. Here, every male in the class signed up with the intent of being interviewed. Although we had a $100 \%$ response rate for the requests, the lead author was only able to interview 19 of the 23 males in the class. This is primarily because the interviews took place each day after school, at the rate of one interview per school day. Over a several week period, a few students did not show up to school on the day of their interview and were unable to fill the afternoon spot. We thus obtained 19 interviews in 2017.

The school offered a private and quiet classroom to conduct the interviews. As the principal investigator was only a few years removed from the participants' age, it was easy for them to relate to the students. We believe that this fostered more emotional openness. All interviews were recorded on a smartphone recorder device, transferred to a laptop and then translated to English when transcribed.

All ethical procedures of the American Sociological Association have been followed, including giving students the right to withdraw and total anonymity. The audio recordings were deleted after they were transcribed, and the transcripts given an anonymous name. Participants were told that they had the right to examine their transcripts, but none requested such.

\section{Analysis}

After collection, the data were transcribed, and at the same time translated into the English language by the lead author. All authors were then provided with the transcripts and an inductive approach was adopted, with the construction of thematic categories based on consistent, repetitive and recurring experiences of related data (Braun and Clarke, 2006). We sought to draw out the key patterns in data that express a level of unanimity in the views expressed by our participants (Joffe, 2012). This approach was also valued for its theoretical flexibility and grounding in data (Braun and Clarke, 2006).

Each author coded the written interviews, following procedures consistent with the 'six-phase' approach outlined by Braun and Clarke (2006, 2012, 2013), and inductively developed their own themes. We then discussed the interviews, the emerging data, and our initial thoughts on potential themes (Urquhart, 2013). The 'themes' or 'codes' were then co-verified across the team, and consensus was met on the following themes presented in this article: (1) positive attitudes toward homosexuality; (2) openness to a bromance with a gay male (dependent on gender typicality); and (3) perceived generational differences in gay acceptance compared to their parents' generation.

These emergent themes were referenced back to the transcripts, and their internal coherence assessed (Braun and Clarke, 2006). We then constructed theoretical arguments from the data (Charmaz, 2014). Whilst we acknowledge the inherently subjective nature of qualitative research (McCormack, 2012), it is through these described procedures that rigour is assured. 


\section{Results}

\section{Attitudes toward homosexuality}

The capital of Czechia - Prague - is a cosmopolitan metropole and it is known for its positive attitudes toward gay culture. However, this study was carried out in more rural part of Czechia, in a town with just 33,000 people. Even though research on American rurality shows that there is less acceptance of homosexuality than within metropolitan areas (Bell and Valentine, 1995; Chauncey, 2008; Gray, 2009; LeVay and Nonas, 1997) that was not as evident in this research.

Instead, the participants, who unanimously hail from this town or smaller villages outside of the town, all espoused relatively positive attitudes toward homosexuality. None of the participants indicated any negative attitudes. Collectively, they suggest that sexuality is not a factor which they would take into consideration in deciding to be friends with someone.

First, it is important to mention that none of the participants would mind having a gay friend. However, just as Anderson (2015) suggests that homosexuality is made more acceptable when it is gender-normative, the participants suggest that hyper-femininity among men might distract them from wanting a friendship with a straight or gay male. Relevant to homosexuality specifically, they also suggest that the gay male should not demand too much physical contact with the straight male friend. As Participant 1 said, 'If he [hypothetical gay male friend] would touch me inappropriately or too often, I would feel weird, because he might want something more from our relationship.' Thirteen other participants suggested something along the lines of what Participant number 2 said, 'I don't have any issues to be a friend with a gay guy. The only thing which decides whether we would become friends or not is mainly his behaviour and character.' When asked for clarification from Participant 6 about what behaviours might not be acceptable, he said:

I differentiate two types of gay guys - first group are the normal gay guys, who don't talk about it too much and so on. Then there is the rest who are kind of too feminine and express the gayness too much. I just judge people on their behaviour. So, as long as he was alright in front of me, I would not care what he does in private life. So, I can be a friend with gay guys, there is no doubt about that, they just need to behave in a decent way.

\section{Participant 5 came up with similar taxonomy:}

I can definitely be a friend with a gay guy it is not about who you sleep with. It is about the behaviour. If I was a friend with a gay guy, he should not be too feminine, and he should not express the gayness too much.

The principal investigator noticed that the 'expressing gayness' is one of the crucial conditions in creating a friendship with gay people for the majority of the participants. Therefore, they were asked for a clarification of what it means to 'express gayness', to which Participant 5 said: 
Like, you know, he doesn't have to go to every gay pride parade. He doesn't have to be wearing pink clothes and kiss other guys in front of me and stuff like that. He just needs to behave in a decent way.

While these qualifications, of what Connell might call a very straight gay (Connell, 1992), are however based in the extreme, the men in this study were not opposed to gay men wearing skinny jeans, talking softly, being uninterested in sports, or other gay associations. It was really a parody of a gay man that they imagined they would not appreciate.

These answers thus indicate that, at least in this part of the rural country, acceptance toward homosexuality is still somewhat conditional upon a relative sense of gender typicality with heterosexual masculinity. And, according to participants, they would feel the same if a heterosexual male acted gender atypically.

Thus, this research indicates that they are accepting of homosexuality, and less tolerant of extreme gender atypicality. This, we note, is also an imagined perspective: as a whole these young men have no actual experience with gay men. In fact, only two participants in this study know a gay person in their social circles while only another eight have ever met a gay male in real life. This means that nine of the men in this study have never even met a gay male. It is therefore possible that their attitudes toward gender atypicality may be revised in the face of contact with someone who met their definitions (Hodson et al., 2009).

Despite the lack of visibility of gay people and gay culture in the participants' community, they nonetheless show relatively positive attitudes toward homosexuality. To evidence this, participants were asked if they would consider being in a bromance with a gay male. Most of the participants reacted in the same way as before: only under certain circumstances (mainly concerning gender-atypicality), but that it was possible.

Of the two participants who actually have a gay friend, both answered that they could, if they shared similar perspectives, be in a bromance with a gay man.

This perspective was shared by those without gay male friends. Participant number 7 said, 'I probably would not mind it to be in a bromance with a gay guy. It just depends on his behaviour.' When asked for specification of the behaviour, he said, 'He could not fancy me, he could not be too feminine and just act like any another friend.' Participant number 8 had a similar answer, 'I have no problems to be in bromance with a gay guy. His behaviour is what decides whether it was possible or not.'

Only two of the 19 participants said they could not be in a bromance with a homosexual. Participant 14 explained: 'I don't think it would work. I might be scared to be $100 \%$ emotionally open in front of him.' The other had no reason as to why.

Another three participants were unsure of being in a bromance with a gay male, but they again pointed out that everything would depend on his behaviour. The rest of the participants $(n=14)$ were open to the idea being in a bromance with a homosexual. All of them, however, mentioned some conditions. For example, Participant number 6 said, 'I could be in bromance with a gay guy for sure. Everything just depends on his behaviour and character. Sexuality doesn't play a big role in creating friends.'

All participants mentioned that factors such as sexuality do not play any considerable role in creating friends. All of them also mentioned that it is only the behaviour which 
decides whether a person becomes a friend or not. Alongside behaviour, other aspects influencing the friendship creation process were mentioned quite frequently, for example, personality and character. Thus, the participants did not show any negative indications toward a different sexuality, they only judge the behaviour, character and personality of other people. Thus, homophobia does not seem to be a helpful tool for analysing these data, but heteronormativity perhaps does.

\section{Perceptions of generational homophobia}

Participants in this study do not hold a personal antipathy toward male homosexuality, but they do believe that older men are not as inclusive. As Czech students, they are very familiar with the homophobic history of their country outlined in the literature review. Although young, these participants highlighted generation differences between them and older men and related this to the 20th century history of Czech people.

A majority of the participants feel a difference in acceptance of gay culture between their generation and the older ones. The difference was mainly perceived $(n=16)$ that younger generations are more open (it is easier for them to accept) to things such as homosexuality. Most of them expressed themselves similarly to Participant 15, who said:

There is a big difference [between millennial and older generations], for example, my grandpa is homophobic they [older people] just can't perceive it as normal. Our generation is more open to these things we don't judge the people on their sexes too much.

Participant 12 observed the progress, for example, in racism in his family:

There surely is a difference between ours and the older generations. Older people are more conservative [xenophobic and racist]. For example, my grandma is pure racist, my father is just little bit racist, not like actively but sometimes he is just in a racist mood. And I am not racist at all. But still, I do not dare to judge which generation is more or less homophobic in general because we do not talk about it.

Several participants mentioned that some of the older members of their family are homophobic and more xenophobic in general. Some of the participants also said that they are unsure if they are able to judge the differences between their generation and the generation of their parents, as they do not discuss topics such as homosexuality at all, like the quote above.

However, one of the participants experienced this difference in real life. The participant was asked what his reaction would be if he got a kiss from his best friend. His response was: 'It already happened.'

When asked for more information about the story, the participant replied:

We were sitting in a pub, there were more of us, and I was already drunk. And the other friends started to encourage him [his best friend] to kiss me. The best friend, drunk as well, just said 'should I kiss you?' I replied that he wouldn't do that anyway. Then he [his best friend] grabbed my head pull me closer and licked my mouth. It was not normal, but I thought it was funny. We all laughed. You never know what my best friend is going to do. 
Several participants suggest that the change is mainly caused by the change of political regime and by technological advancements and media. The negative influence of the former political regime was mentioned frequently. Participant 7, as well as many others, said, 'Our generation is more open to everything and we also know more about it. Older generations are more conservative but that is because of the political history [communism].'

Beside the political history, another factor influencing this change was pivotal for many participants. Participant 9 said: 'We [the millennial generation] are more tolerant to stuff like this [homosexuality, etc.] mainly thanks to the technology. We are better informed through the media and see that often in movies and so on.'

Addressing this statement, participants of this study are the first generation raised in a free democratic state, with freedom of speech and the right to freely cross the Czech border. The millennial generation has been significantly influenced by the internet and all the new technological advancements which were being imported into Czechoslovakia and later to the Czech Republic after the fall of communism. As Participant number 19 said, 'With internet, everything is easier. If you have got any issues or troubles you can always find people on the internet who suffered from similar problem and they can help you out.' Participant 4 also suggested that 'Thanks to the internet and media such as movies it is easier to accept new things and realise that things like homosexuality is actually normal.'

\section{Discussion}

Anderson's (2009) Inclusive Masculinity Theory has been used as a framework for the investigation of changing masculinities in multiple countries. To date, however, the theory has not been used as a framework for an investigation in Central Europe. Given the instability of masculinity, along with cultural variance, it is imperative to study men and their masculinity instead of generalizing results from other nations' studies. It is for this reason that we have studied the relationship between masculinity and decreasing homophobia in the Central European country of Czechia.

Central to Anderson's (2009) Inclusive Masculinity Theory is the cultural disposition toward gay men. Like other Western countries, Czechia improved the legal and (likely) cultural treatment of gay men throughout the latter decades of the 20th century. Homosexual sex was decriminalized in 1962, and anti-discrimination rights in accessing the goods and services came in 2001. Registered partnership for same-sex couples was instituted in 2006. While Czechia does not yet have gay marriage, it appears to be forthcoming. In 2018, most parliament members signed a petition to say that same-sex marriage should soon replace registered partnership (Ver, 2018). Thus, equality and diversity are continuously improving in Czechia, and they appear to be improving in line with other Western nations.

In order to examine the relationship between increased acceptance of homosexuality and adolescent masculinities, we located 19 male millennial participants aged 18-20. They all self-identified as heterosexual and white, hailing from a rural part of the country. We then modelled the research approach of other studies of inclusive masculinities, using a semi-structured interview schedule in order to ask the same questions of each 
participant. Questions generally focused on gay acceptance, and generational differences in the perception of masculinity in Czechia.

Consistent with other studies (Adams, 2011; Anderson, 2008; Bush et al., 2012; McCormack and Anderson, 2010), the results of this study indicate that the masculinity in Czechia is becoming more inclusive. Firstly, Anderson (2009) suggests that inclusive masculinities are borne out of acceptance of male homosexuality. We examined the general acceptance of gay men among the participants, finding them to have very positive attitudes regarding this issue. This may exist as a surprising finding, as some studies of America show that rural men are less accepting of homosexuality than urban men (Fellows, 1998).

Not only did the participants say that they would not mind having a male homosexual friend, but, similar to findings among British males of this age cohort, the majority of them suggested that they would not mind being in a bromance with a gay male (Robinson et al., 2018, 2019). The qualifying criterion was commonality, which included gender typicality.

We also addressed the generational difference regarding inclusive masculinity from participants' point of view compared to men of their fathers' age cohort. Here, 16 out of 19 participants recognized a difference and suggested that their generation is more inclusive regarding homophobia (participants' generation holds more positive attitudes toward homosexual men). The rest of the participants $(n=3)$ were not able to judge. Given the general acceptance of gay men, combined with a belief that the generation of men above the participants were not as accepting, results seem broadly in alignment with the cohort analysis of men in Britain recently published (Anderson and Fidler, 2018).

The positive results about male homosexuality found among the participants should also take into consideration one variable of difference from other Western studies. The men in this study seem to have less contact with gay men than men in other cultural studies of IMT. Given that research shows that contact with gay men promotes positive attitudes toward homosexuality (Hodson et al., 2009) and given that national polls show Czechia to have less religiosity than other Western countries (Spousta, 2002; Staar, 1971), it is conceivable that the men in this study - despite existing within a rural location within this country - would have elevated rates of positive attitudes toward gay men if they actually knew some. Still, even without much social contact with openly gay men in this small Czech town, the 19 participants showed that masculinity in Czechia is becoming more inclusive than it used to be.

The results of this study, where only two factors of IMT were addressed (attitudes toward homosexuality and comparing generational attitudes), suggest that the future development of masculinity in Czechia could follow the English forms of masculinity so widely discussed in the research literature (e.g. Adams, 2011; Anderson and McGuire, 2010; Morris and Anderson, 2015). This should mean that future investigations of millennial and younger men in Czechia would show less hierarchical stratifications than perhaps even exists in other Western nations.

\section{Declaration of conflicting interest}

The authors declared no potential conflicts of interest with respect to the research, authorship, and/ or publication of this article. 


\section{Funding}

The authors received no financial support for the research, authorship, and/or publication of this article.

\section{ORCID iD}

Jack Hardwicke (iD https://orcid.org/0000-0002-1152-0920

\section{References}

Adams A (2011) 'Josh wears pink cleats': Inclusive masculinity on the soccer field. Journal of Homosexuality 58(5): 579-596.

Adams A and Kavanagh E (2018) Inclusive ideologies and passive performances: Exploring masculinities and attitudes toward gay peers among boys in an elite youth football academy. Journal of Gender Studies 27(3): 313-322.

Anderson E (2002) Openly gay athletes: Contesting hegemonic masculinity in a homophobic environment. Gender \& Society 16(6): 860-877.

Anderson E (2005) Orthodox and inclusive masculinity: Competing masculinities among heterosexual men in a feminized terrain. Sociological Perspectives 48(3): 337-355.

Anderson E (2008) Inclusive masculinity in a fraternal setting. Men and Masculinities 10(5): $604-620$.

Anderson E (2009) Inclusive Masculinity: The Changing Nature of Masculinities. Abingdon: Routledge.

Anderson E (2011) The rise and fall of western homohysteria. Journal of Feminist Scholarship 1(1): 80-94.

Anderson E (2015) Assessing the sociology of sport: On changing masculinities and homophobia. International Review for the Sociology of Sport 50(4-5): 363-367.

Anderson E (2018) Generational masculinities. Journal of Gender Studies 27(3): 243-247.

Anderson E and Fidler CO (2018) Elderly British men: Homohysteria and orthodox masculinities. Journal of Gender Studies 27(3): 248-259.

Anderson E and McCormack M (2018) Inclusive masculinity theory: Overview, reflection and refinement. Journal of Gender Studies 27(5): 547-561.

Anderson E and McGuire R (2010) Inclusive masculinity theory and the gendered politics of men's rugby. Journal of Gender Studies 19(3): 249-261.

Anderson E and Magrath R (2019) Men and Masculinities, 1st edn. Abingdon: Routledge.

Anderson E, Adams A and Rivers I (2012a) 'I kiss them because I love them': The emergence of heterosexual men kissing in British institutes of education. Archives of Sexual Behavior 41(2): 421-430.

Anderson E, McCormack M and Lee H (2012b) Male team sport hazing initiations in a culture of decreasing homohysteria. Journal of Adolescent Research 27(4): 427-448.

Anderson E, Ripley M and McCormack M (2019) A mixed-method study of same-sex kissing among college-attending heterosexual men in the US. Sexuality \& Culture 23: 26-44.

Baker PL and Hotek DR (2011) Grappling with gender: Exploring masculinity and gender in the bodies, performances, and emotions of scholastic wrestlers. Journal of Feminist Scholarship 1(Fall): 49-64.

Bell D and Valentine G (1995) Queer country: Rural lesbian and gay lives. Journal of Rural Studies 11(2): 113-122.

Borkowska K (2018) Approaches to studying masculinity: A nonlinear perspective of theoretical paradigms. Men and Masculinities 23(3-4): 409-424. 
Brannon R and David D (1976) The male sex role: Our culture's blueprint of manhood, and what it's done for us lately. In: Brannon R and David D (eds) The Forty-Nine Percent Majority: The Male Sex Role. Boston: Addison Wesley, pp. 1-48.

Braun V and Clarke V (2006) Using thematic analysis in psychology. Qualitative Research in Psychology 3(2): 77-101.

Braun V and Clarke V (2012) Thematic analysis. In: Cooper H, Camic PM, Long DL et al. (eds) APA Handbook of Research Methods in Psychology, Vol. 2. Research Designs: Quantitative, Qualitative, Neuropsychological, and Biological. Washington, DC: American Psychological Association, pp. 57-71.

Braun V and Clarke V (2013) Teaching thematic analysis: Overcoming challenges and developing strategies for effective learning. Psychologist 26(2): 120-123.

Burjanek A and Retter A (2001) Xenophobia among the Czech population in the context of postcommunist countries and Western Europe. Czech Sociological Review 9(1): 53-67.

Burstyn V (1999) The Rites of Men: Manhood, Politics, and the Culture of Sport. Toronto: University of Toronto Press.

Bush A, Anderson E and Carr S (2012) The declining existence of men's homophobia in British sport. Journal for the Study of Sports and Athletes in Education 6(1): 107-120.

Charmaz K (2014) Constructing Grounded Theory, 2nd edn. London: Sage.

Chauncey G (2008) Gay New York: Gender, Urban Culture, and the Making of the Gay Male World, 1890-1940. London: Hachette UK.

Clements B and Field CD (2014) Public opinion toward homosexuality and gay rights in Great Britain. Public Opinion Quarterly 78(2): 523-547.

Connell RW (1987) Gender and Power: Society, the Person and Sexual Politics. Stanford, CA: Stanford University Press.

Connell RW (1992) A very straight gay: Masculinity, homosexual experience, and the dynamics of gender. American Sociological Review 57(6): 735-751.

Connell RW (1995) Masculinities: Power and Social Change. Berkeley: University of California Press.

Connell RW and Messerschmidt JW (2005) Hegemonic masculinity: Rethinking the concept. Gender \& Society 19(6): 829-859.

Courtenay WH (2000) Constructions of masculinity and their influence on men's well-being: A theory of gender and health. Social Science \& Medicine 50(10): 1385-1401.

DeAngelis M (2014) Reading the Bromance: Homosocial Relationships in Film and Television. Detroit: Wayne State University Press.

Derlega VJ, Catanzaro D and Lewis RJ (2001) Perceptions about tactile intimacy in same-sex and opposite-sex pairs based on research participants' sexual orientation. Psychology of Men \& Masculinity 2(2): 124-132.

Drummond MJ, Filiault SM, Anderson E and Jeffries D (2015) Homosocial intimacy among Australian undergraduate men. Journal of Sociology 51(3): 643-656.

Erban O (2015) Zivot gayu za komunismu v Ceskoslovensku. Available at: www.vice.com/cs/ article/jpx9ay/zivot-gayu-za-komunismu-v-cechach (accessed 30 September 2018).

Fellows W (ed.) (1998) Farm Boys: Lives of Gay Men from the Rural Midwest. Madison: University of Wisconsin Press.

Floyd K (2000) Affectionate same-sex touch: the influence of homophobia on observers' perceptions. The Journal of Social Psychology 140(6): 774-788.

Gray ML (2009) Out in the Country: Youth, Media, and Queer Visibility in Rural America. New York: NYU Press.

Hasan MK, Aggleton P and Persson A (2018) The makings of a man: Social generational masculinities in Bangladesh. Journal of Gender Studies 27(3): 347-361. 
Hodson G, Harry H and Mitchell A (2009) Independent benefits of contact and friendship on attitudes toward homosexuals among authoritarians and highly identified heterosexuals. European Journal of Social Psychology 39(4): 509-525.

$\mathrm{Hu}$ L (2018) Is masculinity 'deteriorating' in China? Changes of masculinity representation in Chinese film posters from 1951 to 2016. Journal of Gender Studies 27(3): 335-346.

Janda M (2010) Železná opona: hranice mezi dvěma světy. 21. Stoleti. Available at: https://21 stoleti. cz/2010/12/22/zelezna-opona-hranice-mezi-dvema-svety/ (accessed 11 October 2018).

Joffe H (2012) Thematic analysis. In: Harper D and Thompson AR (eds) Qualitative Research Methods in Mental Health and Psychotherapy: A Guide for Students and Practitioners, 1st edn. Chichester: Wiley-Blackwell.

Kaplan D (2006) The Men We Loved: Male Friendship and Nationalism in Israeli Culture, 1st edn. New York: Berghahn Books.

Kimmel M (1995) Manhood in America. New York: Free Press.

Kinsey AC, Pomeroy WB, Martin CE and Sloan S (1948) Sexual Behavior in the Human Male, Vol. 1. Philadelphia: Saunders.

Kuznik J and Beranek J (2005) Za komunistů zabíjel na hranicích elektrický proud a miny. Available at: https://technet.idnes.cz/za-komunistu-zabijel-na-hranicich-elektricky-prouda-miny-pm9-/tec_reportaze.aspx?c=A051116_180110_tec_checktech_kuz (accessed 11 October 2018).

LeVay S and Nonas E (1997) City of Friends: A Portrait of the Gay and Lesbian Community in America. Cambridge, MA: MIT Press.

Lorber J (1994) Paradoxes of Gender. New Haven, CT: Yale University Press.

McCormack M (2011) Hierarchy without hegemony: Locating boys in an inclusive school setting. Sociological Perspectives 54(1): 83-101.

McCormack M (2012) The Declining Significance of Homophobia: How Teenage Boys are Redefining Masculinity and Heterosexuality. Oxford: Oxford University Press.

McCormack M and Anderson E (2010) 'It's just not acceptable any more': The erosion of homophobia and the softening of masculinity at an English sixth form. Sociology 44(5): 843-859.

McCormack M and Anderson E (2014a) Homohysteria: Definitions, context and intersectionality. Sex Roles 71(3-4): 152-158.

McCormack M and Anderson E (2014b) The influence of declining homophobia on men's gender in the United States: An argument for the study of homohysteria. Sex Roles 71(3-4): $109-120$.

McCreary DR (1994) The male role and avoiding femininity. Sex Roles 31(9): 517-531.

Magrath R (2016) Inclusive Masculinities in Contemporary Football: Men in the Beautiful Game. Abingdon: Taylor \& Francis.

Magrath R and Scoats R (2017) Young men's friendships: Inclusive masculinities in a post-university setting. Journal of Gender Studies 28(1): 45-56.

Magrath R, Anderson E and Roberts S (2015) On the door-step of equality: Attitudes toward gay athletes among academy-level footballers. International Review for the Sociology of Sport 50(7): 804-821.

Martin PY and Hummer RA (1989) Fraternities and rape on campus. Gender \& Society 3(4): 457-473.

Morris M and Anderson E (2015) 'Charlie is so cool like': Authenticity, popularity and inclusive masculinity on YouTube. Sociology 49(6): 1200-1217.

Overy RJ (2004) The Dictators: Hitler's Germany and Stalin's Russia. New York: WW Norton \& Company. 
Philip S (2018) A city of men? An ethnographic enquiry into cultures of youth masculinities in urban India. $\mathrm{PhD}$ thesis, University of Oxford.

Plummer D (1999) One of the Boys: Masculinity, Homophobia, and Modern Manhood. Hove: Psychology Press.

Posters.nce (n.d.) http://posters.nce.buttobi.net/czech1.htm

Pyšňáková M and Miles S (2010) The post-revolutionary consumer generation: 'Mainstream' youth and the paradox of choice in the Czech Republic. Journal of Youth Studies 13(5): 533-547.

Roberts S (2013) Boys will be boys. . . won't they? Change and continuities in contemporary young working-class masculinities. Sociology 47(4): 671-686.

Roberts S (2018) Domestic labour, masculinity and social change: Insights from working-class young men's transitions to adulthood. Journal of Gender Studies 27(3): 274-287.

Roberts S (ed.) (2014) Debating Modern Masculinities: Change, Continuity, Crisis? Berlin: Springer.

Robinson S, Anderson E and White A (2018) The bromance: Undergraduate male friendships and the expansion of contemporary homosocial boundaries. Sex Roles 78(1-2): 94-106.

Robinson S, White A and Anderson E (2019) Privileging the bromance: A critical appraisal of romantic and bromantic relationships. Men and Masculinities 22(5): 850-871.

Ross L (1999) The Divine Nine: The History of African American Fraternities and Sororities. New York: Kensington Books.

Sanday PR (1990) Fraternity Gang Rape: Sex, Brotherhood, and Privilege on. New York: New York University Press.

Savin-Williams RC (2009) The New Gay Teenager, Vol. 3. Cambridge, MA: Harvard University Press.

Šmídová I (2009) Changing Czech masculinities? Beyond 'environment and children friendly' men. In: Oleksy EH (ed.) Intimate Citizenships: Gender, Sexualities, Politics (Routledge Research in Gender and Society), 1st edn. Abingdon: Routledge, pp. 312-334.

Sokolová V (2014) State approaches to homosexuality and non-heterosexual lives in Czechoslovakia during state socialism. In: Havelková H and Oates-Indruchová L (eds) The Politics of Gender Culture under State Socialism: An Expropriated Voice. Abingdon: Routledge, pp. 82-108.

Spousta J (2002) Changes in religious values in the Czech Republic. Czech Sociological Review 38(3): 345-363.

Staar RF (1971) Communist Regimes in Eastern Europe. Stanford, CA: Hoover Institution Press.

Twenge JM, Sherman RA and Wells BE (2016) Changes in American adults' reported same-sex sexual experiences and attitudes, 1973-2014. Archives of Sexual Behavior 45(7): 1713-1730.

Urquhart C (2013) Grounded Theory for Qualitative Research. London: Sage.

Ver (2018) Vláda podpořila manželství pro homosexuály, registrované partnerství by tím zaniklo. Available at: https://ct24.ceskatelevize.cz/domaci/2517118-vlada-podporila-manzelstvi-prohomosexualy-registrovane-partnerstvi-tim-zaniklo (accessed 19 November 2018).

Vilanova A, Soler S and Anderson E (2018) Examining the experiences of the first openly gay male team sport athlete in Spain. International Review for the Sociology of Sport 55(1): 22-37.

Vrangalova Z and Savin-Williams RC (2012) Mostly heterosexual and mostly gay/lesbian: Evidence for new sexual orientation identities. Archives of Sexual Behavior 41(1): 85-101.

Walker C (2016) Stability and precarity in the lives and narratives of working-class men in Putin's Russia. Social Alternatives 34(4): 28-34.

Walker C (2017) 'I just don't want to connect my life with this occupation': Working-class young men, manual labour, and social mobility in contemporary Russia. British Journal of Sociology 69(1): 207-225.

Way N (2011) Deep Secrets. Cambridge, MA: Harvard University Press. 


\section{Author biographies}

Viktor Chvatik is a postgraduate research student at the University of Winchester. His research focuses on masculinities amongst youth and in sport settings.

Jack Hardwicke is a Lecturer in Health Sociology at the University of Northampton. His research focuses on masculinities in sport, physical activity promotion and sexual minorities experiences in sport.

Eric Anderson is an American sociologist and sexologist specializing in adolescent men's gender and sexualities. He holds the position of Professor of Masculinities, Sexualities and Sport at the University of Winchester, in England.

\section{Résumé}

Dans cette première enquête sur les masculinités inclusives parmi des étudiants tchèques de 18 et 19 ans, nous avons interrogé 19 participants d'une région rurale du pays. L'objectif de cette recherche était d'identifier les attitudes des jeunes hommes tchèques ruraux envers l'homosexualité et d'examiner la différence générationnelle perçue par rapport à leurs homologues qui ont connu le communisme. Les résultats apportent des preuves de masculinités inclusives pour ces jeunes ruraux, basées sur trois catégories principales : I) attitudes positives envers l'homosexualité ; 2) ouverture à une bromance (relation affective forte sans composante sexuelle) avec un homme gay (en fonction de la typicité de genre) et 3) différences générationnelles perçues dans l'acceptation des gays par rapport à la génération de leurs parents. Dans l'ensemble, les résultats montrent donc que les jeunes hommes de cette région rurale de la Tchéquie adoptent des formes de masculinité plus inclusives que celles qui étaient possibles sous le régime communiste.

\section{Mots-clés}

Genre, jeunesse, masculinité inclusive, milieu rural

\section{Resumen}

En esta primera investigación sobre masculinidades inclusivas entre estudiantes checos de 18 y 19 años, se entrevista a 19 participantes de una zona rural del país. El propósito de esta investigación es identificar las actitudes de los hombres jóvenes, rurales checos hacia la homosexualidad y examinar la diferencia generacional percibida en comparación con los hombres que emergieron bajo el comunismo. Los resultados muestran evidencia de masculinidades inclusivas para estos jóvenes rurales, basadas en tres categorías principales: I) actitudes positivas hacia la homosexualidad; 2) apertura a un bromance (vínculo afectivo intenso no sexual) con un hombre gay (dependiendo de la tipicidad de género) y 3) diferencias generacionales percibidas en la aceptación de lo gay en comparación con la generación de sus padres. En general, los resultados muestran, por tanto, que los hombres jóvenes en esta parte rural de Chequia están adoptando formas de masculinidad más inclusivas que las que eran posibles bajo el régimen comunista.

\section{Palabras clave}

Género, juventud, masculinidad inclusiva, zonas rurales 